\title{
Bulk grass seed drying and storage
}

\author{
C. J. Crosbie \\ Ministry of Agriculture and Fisheries, Christchurch
}

\begin{abstract}
The basic principles of drying and storing bulk lots of grass seed are briefly described. The importance of cooling field-dried lines before storage in order to prevent heating in the silo and seed damage from thermophyllic fungi is stressed.

Key words: Grass seed drying, grass seed storage, Aspergillus glaucus.
\end{abstract}

\section{INTRODUCTION}

Following the advent of the bulk header in the late fifties and the introduction of continuous flow driers in 1961, the way was opened for bulk handling and drying lines of grass seed. The home construction of in-bin driers by fitting fans to silos and the special farm-built grass seed driers greatly popularized this move. It was now possible to dry lines that had been harvested out of condition and initiate a new harvest technique designed to reduce field losses by deliberately threshing early after mowing (say 48 hours) and drying the resultant crop (Crosbie, 1974).

Using the in-bin drier principle, directheaded grass seed of about $45 \%$ moisture content can be dried in a layer $0.9 \mathrm{~m}$ deep on the lloor. Seed of 17 to $21 \%$ moisture content is dried in layers $1.5 \mathrm{~m}$ deep.

Dry seed can be stored in masses up to $6 \mathrm{~m}$ deep provided it is cooled at an early date preferably each night in successive layers 1.5 to $1.8 \mathrm{~m}$ deep as the silo is filled.

\section{The FAN}

The recommended air flow is 20 cubic feet per minute per square foot of drying floor $\left(0.1 \mathrm{~m}^{3} / \mathrm{s}\right.$ per $\left.1 \mathrm{~m}^{2}\right)$. A pressure of 1 inch water gauge (w.g.) per foot of depth is required to pass this air flow through the mass (2.5 cm water gauge per $30 \mathrm{~cm}$ depth). Thus for seed $5 \mathrm{ft}$ deep on a $15 \mathrm{ft} \times 20 \mathrm{ft}$ $\left(300 \mathrm{ft}^{2}\right)$ floor, the fan is required to produce $6000 \mathrm{cu} . \mathrm{ft} / \mathrm{min}$ at a pressure of $5 \mathrm{in}$. w.g. i.e., for seed $1.5 \mathrm{~m}$ deep on a $4.6 \mathrm{~m}$ x $6.1 \mathrm{~m}$ $\left(28 \mathrm{~m}^{2}\right)$ floor the fan is required to produce $28 \mathrm{~m}^{2} \times 0.1 \mathrm{~m}^{3} / \mathrm{s}\left(2.8 \mathrm{~m}^{3} / \mathrm{s}\right)$ at a pressure of $12.5 \mathrm{~cm} \mathrm{w.g.}$

\section{AIR}

There is a relationship between the relative humidity (r.h.) of the air and the moisture content (m.c.) of the seed such that a balance is achieved between the two when seed is exposed to the air for long periods. Thus air of about $65 \%$ r.h. is in balance with $14 \% \mathrm{~m} . c$. in ryegrass and $12 \%$ m.c. in cocksfoot seed these are the safe levels of moisture for the bulk storage of the two seeds.

As happens during most nights when dew falls and the r.h. of the air rises to $100 \%$, this damp air is in balance with grass seed of about $23 \%$ m.c. The r.h. of such air can be corrected back to $65 \%$ by warming it by 4 to $5^{\circ} \mathrm{C}$.

\section{HeATING AIR}

Where the fan is powered by a tractor or a petrol or diesel motor there is usually sufficient waste heat lost by the power unit to warm the air by 4 to $5^{\circ} \mathrm{C}$. This is achieved by building a house over the fan and power unit, and possibly also by fitting a heat exchanger to the exhaust pipe. Where electric motors are used to drive the fan, an electric heater or a diesel gun burner and tire-box must be used to warm the air.

\section{Drying Grass Seed}

Compared with grain drying, drying grass seed is fast: $1 \%$ of m.c. can be removed in 4,5 or 6 hours depending on the weathel 
(warm airs have a greater capacity to take up moisture than cold airs). Thus, a line of seed harvested at $21 \%$ m.c. down to $17 \%$ has an average m.c. of $19 \%$ and requires $5 \%$ removal to reach $14 \%$ for safe storage. This will be dried in 20 to 30 hours depending on the weather. The air first dries a zone about 60 $\mathrm{cm}$ deep at the bottom of the mass, and thereafter the drying zone moves up until it reaches the top, when drying is completed

\section{MEASURING MoIsture}

The infrared moisture tester is the most reliable unit for testing moisture in grass seed (and in hay) and is a "must" for all serious seed growers. When the base of the heat lamp is fitted on a $10 \mathrm{~cm}$ block of wood, the tester can be made to read continuously to facilitate its use.

\section{Cooling Grass Seed}

Lines of seed that dry naturally in the field require to be cooled if they are to store safely in bulk. Such lines come in hot from the field (as high as $44^{\circ} \mathrm{C}$ in one instance) and continue to heat in the silo due to the action of a mould, Aspergilfus glaucus, with resultant loss of germination. A sample of seed from the centre of such a heated silo tested nil germination.

The action of these moulds can be prevented by cooling the seed by blowing cold air through it at night. Some wetting back of the bottom layers will occur and the seed can be cooled down to within 4 to $5^{\circ} \mathrm{C}$ of ambient (Crosbie, 1972).

\section{Instruments REOUIRED}

1 infrared moisture tester.

2 thermometers - one for the air duct and one on a probe in the seed.

1 hygrometer (wet and dry bulbs).

1 seed sampling spear.

1 length of clear plastic tube (any diameter) for water gauge.

1 notebook.

\section{REFERENCES}

Crosbie, C. ., 1972. Heat damage and small seeds. Advis. Serv. Div., MAF, Christchurch. 1974. Grass seed drying. Advis. Serv. Div., MAF. Christchurch. 